\title{
HOW SMALL SUPPLIERS DEAL WITH THE BUYER POWER IN ASYMMETRIC RELATIONSHIPS WITHIN THE SUSTAINABLE FASHION SUPPLY CHAIN
}

\section{INTRODUCTION}

The concept of power is widespread and it can be easily observed in supplier-retailer studies because in asymmetric exchange relationships, retailers are the powerful side and they are able to set the rules of the game (Hingley et al., 2015). A number of researchers in supply chains (Nyaga et al., 2013, Rindt and Mouzas, 2015) have explored power asymmetry. In asymmetric supplier-buyer relationships, the powerful partner applies its power in two main areas: the strategic and operational areas of the weaker party. This means that the weaker party accepts the control of the powerful party in its business activities in both areas (Johnsen and Ford, 2008).

This paper investigates how small suppliers deal with buyer power within the sustainable fashion supply chain. The term sustainable fashion supply chain in this paper reflects Seuring and Muller's (2008, p. 1700) definition who defined the sustainable supply chain 'as the management of material, information and capital flows as well as cooperation among companies along the supply chain while taking goals from all three dimensions of sustainable development.' The paper takes an interaction approach (IMP Group,1982) to develop a better understanding of the application of power by retailers and contributes to Munksgaard, Johnsen and Patterson (2015) call for further research into buyer-supplier relationships. This need for further research is particularly warranted in the area of fashion supply chain relationships in relation to increasing exertion of power by retailers (Oxborrow and Brindley, 2014). The fashion supply chain is characterised by powerful retail buyers and small fashion suppliers. Major retail buyers increasingly appear to gain relative power which adds extra pressure on small supplier firms to sustain their relationships (Hines and McGowan, 2005). 
This study focuses on the application of power by large fashion retailers in asymmetric relationships within the fashion supply chain.By undertaking a qualitative study on Turkish suppliers the paper offers a deeper understanding in regard to both geographical aspects of supply chain and the impacts on relational development because one of the important factors, which determine sustainability practices in fashion supply chain, is globalisation of sourcing and distribution. In the last two decades, textile and fashion manufacturing has move to developing economies (MacCarthy and Jayarathe, 2010). Turkey is the world's seventh largest clothing exporter (Foreign and Commonwealth Office, 2014). Turkish fashion suppliers have developed key competencies that have enabled strong partnerships with geographically distant retail buyers but Tokatli and Kizilgün (2009)have questioned the sustainability of these partnerships as a result of asymmetrical power in supply chains.

The paper has the following research objectives:

1. To identify the application of power within sustainable fashion supply chains.

2. To understand how fashion suppliers deal with the retail buyers' power within the sustainable fashion supply chains.

3. To understand the implications of power application for sustainable fashion supply chains.

We wished to explore the application of power within sustainable fashion supply chains as previous research had been fragmented and not clear in this regard. The conflicting arguments were not clear about the application of power whether it is detrimental to sustainable supply chains or benefits to its stabilisation (Seuring\& Muller, 2008; Toubolic et al., 2014 and Toubolic and Walker 2015a). Secondly, it was evident that suppliers continued to be involved in sustainable supply chain relationships, dealing with adaptation of new processes and collaborating with retail buyers (Chen et al., 2017; Toubolic et al., 2014; 
Seuring and Muller, 2008; Vachon \& Klassen, 2008), and it was this point that directed us to our second objective, how fashion suppliers deal with the retail buyers' power. The third objective stemmed from the fact that globalised fashion supply chains in sourcing and distribution and ongoing power issues have provided a suitable research platform to understand the implication of power application for sustainable supply chains (MacCarthy and Jayarathe, 2010).

The main findings of the research derived from our first objective, identified power applications, mainly in the operational and strategic areas to achieve economic, environmental and social goals within sustainable supply chains as forms of enforcement of collaborations and extension of responsibilities. The second objective: collaborating and adopting processes to create inter-dependencies in a number of ways was used by the fashion suppliers as response to power application. The third objective demonstrates the evaluation of power application and its implications for fashion supply chains a deeper and longer involvement of retail buyers in order to prevent risks and collaborative opportunities with fashion suppliers.

The theoretical contribution of our research is that it is among the first to examine the application of power within sustainable fashion supply chains. We built a typology that guided us to examine the application of power and suppliers' responses in relation to three dimensions of sustainability (economic, environmental and social). The sustainability typology demonstrated a new approach to understand power asymmetry and sustainability within supply chain context. The utilisation of the typology, has added a further dimension to the work of the Industrial Marketing Purchasing (IMP) school and the interaction approach (e.g. Ford et al., 1986; Hakansson \&Snehota, 1995; Gadde \& Hakansson, 2001) and filled the gap in the IMP view that has been identified by (Johnsen et al 2016). Our empirical contribution has been directed towards the exploration of the perspective of fashion suppliers 
in the asymmetric relationships in Turkey. The issues have previously been compounded by the need to overcome difficulties in reaching and convincing fashion suppliers to participate in academic studies. The approach adopted has provided direction for addressing this constant challenge for researchers in the sustainable supply chain field.

The paper begins with a review of the literature before moving on to explore the experiences of six small fashion suppliers.In the next section, a literature review of power within sustainable supply chain relationships is presented. The paper continues with a discussion of the research methodology and the findings from the case studies. The paper draws conclusions and ends with an examination of theoretical and managerial implications of the research, and the future research and limitations.

\section{LITERATURE REVIEW}

\section{Definition of power in supply chains}

Power has been conceptualised and received much attention from a number of researchers (Ireland and Webb, 2007; and Chicksand, 2015, Nyaga et al., 2013). Exertion of power (Thomas et al.,, 2010), and the origin of power (Meehan and Wright, 2012) and dynamics of power (Cox, 2004; Hingley, 2005; Lacoste \& Johnsen, 2015), the use of power (Rindt\& Mouzas, 2015; Nyaga et al., 2013), and the measurement of power (Belaya, Gagalyuk, \&Hanf, 2009).

Alternative views of power tend to focus on power in terms of interdependencies on resources and economic terms: payoffs and cost (Belaya et al., 2009).In supply chain literature, a number of studies have focused on the concept of power in buyer-supplier relationships (Benton \&Maloni, 2005; Meehan \& Wright, 2012; Toubolic et al., 2014). These studies have a consensus of the central importance of power to understand supply chains and the parties involved (Cox, 2001). In this regard, the commonly accepted definition of power 
in supply chain relations is Emerson's (1962, p: 32)"the ability of an actor to influence another to act in the manner that they would not have otherwise" provides us a guidance in this research as power relationships are examined within supply chains.

Moreover, power has been seen as destructive in buyer-supplier relationships (Nyaga et al., 2013). Newer research in supplier-buyer relations has stated that power can also be used to the advantage of suppliers by focusing on the business processes of their customers and creating inter-dependencies, known as countervailing power (Lacoste \& Johnsen, 2015). In the same vein, Pagell et al., (2010) argued that buyer power is not destructive and it is applied in order to achieve sustainability goals in supply chains and suppliers are treated as strategic partners.

\section{Sustainable supply chain}

The concept of sustainability has been mainly considered in the three areas where organisations' activities concern theenvironment, economy and society. The organisations within supply chains are to overcome environmental and social concerns while the economic dimension is not ignored (Elkington, 2002). Seuring and Muller's (2008, p. 1700) have pointed out the three dimensions of sustainability in their definition and it is consistent with the view of sustainable supply chain in this research.

The concept of power and power relationships in sustainable supply chain research is still limited (Walker et al., 2012). Most researchers focused on large organisations and their sustainability practices usually involved with small suppliers (Lee \& Klassen, 2008; Walker

\& Preuss, 2008). This demonstrated the fact that there is a degree of power asymmetry in large buyer and small supplier relationships within supply chains but this power asymmetry may influence the implementation of sustainability and possible outcomes within supply chains (Pedersen \& Andersen, 2006; Millington, 2008). 


\section{Interaction Approach}

The characteristics of customer-supplier relationships are linked to the Industrial Marketing and Purchasing Group's (IMP) interaction model (IMP Group, 1982). The model sees dyadic relationships as frequently long-term, often becoming institutionalized, and viewed through variables describing the participants in the interaction process, the elements and process of interaction, the atmosphere affecting and influencing the interaction and the environment within which interaction takes place. The atmosphere of a relationship is described in terms of the power-dependence relationship between the parties: conflict and/or co-operation, overall closeness or distance and mutual expectations. The relative position of power, and the extent to which this power extends, may influence the level of all (IMP Group, 1982). Relationships between two parties are rarely equal, therefore there will be issues of power balance, control and dependency to resolve or cope with for each party (Ford et al., 1986). Furthermore, there are a number of researchers who haveconceptualised supply chain relationships and networks in the field of industrial marketing and purchasing (IMP Group, e.g. Ford, 1980; Håkansson 1987; Ford et al., 1986). However, Johnsen et al (2016)'s research found that a large proportion of sustainable purchasing and supply chain management research has adopted stakeholder theory, institutional theory or resource-based perspectives but very few papers have adopted an IMP Interaction Approach in sustainable supply chain research.

\section{Application of Power in Supply Chain Relationships}

Powerful retailers pressurise suppliers into adopting their practices that leads to various concerns about long-term relationships in supply chains. Therefore, appropriate practices should be developed to minimize that pressure and applicable inducements can be implemented for the increased exchange of information between these partners in asymmetric relationships (Maglaras et al., 2015). Otherwise, weaker organisations less likely to 
collaborate with powerful organisations because this is a risk for the weaker organisationsbecause theymight not gain benefit from the collaboration and become dependent on a single organisation (Cox et al., 2007) and this also make some difficulties for suppliers to overcome power asymmetries (Lee and Johnsen, 2012). On the other hand, powerful organisations less likely to form and maintain long-term relationships as a result of increasing collaboration and dependence on suppliers (Casciaro \&Piskorski, 2005).

Power asymmetry often indicates the fact that coercion is the major way to apply power(Hausman \& Johnston, 2010). Coercive power uses penalty rather than reward to control another party (Benton \&Maloni, 2005, and Terpent\&Ashenbaum, 2012). However, Gaski (1984) has criticised this because it was ignoring the other effects that may be positive in supply chain relationships. Moreover, power asymmetries have been considered as close to coerciveness, because coercive power may often be found where the level of commitment is low or frequent conflicts when one party is dependent on the other party in relationships(Dwyer, 1980, Ford et al., 2003). Furthermore, coercive powerdiminishes the chance of cooperation between parties and long-term successes and stability (Kumar et al., 1995). As opposed to coercive power, non-coercive power affects the relationships positively by increasing the motivation level, cooperation and offering more involvement opportunities in relationships for the weaker party (Lacoste \& Johnsen, 2015) and less conflict (Hausman\& Johnston, 2010). Therefore, a cautious application of power can, however, encourage supply chain integration and supports the performance goal achievement of powerful organisation through a clear understanding its suppliers' difficulties and support them (Maloni\& Benton, 2000). In contrast to traditional supply chain, there is a lack of understanding how power is applied and what role it plays in sustainable supply chains (Toubolic et al., 2014).

Supplier-buyer relationships develop with buyer domination and with a focus on cost reduction rather than responsiveness, trust and commitment not easily achieved (Johnsen and 
Ford, 2006). Trust and commitment are critical to the development of mutually beneficial relationships (van Hoek, 2000). Johnsen et al. (2006; after Sako, 1998) identify varying levels of trust which emerge as commitment develops. Crook and Combs (2007) argued that the application of power is more important than structure of power relations because it influences relationship partners' willingness to adapt or collaborate in relationships. The strong association between coercive power and compliance has gained much attention from researchers, leading them to disregard research on power by focusing more on influence and cooperation and issues related to power in networks, although the actual application of power in networks and interactions are neglected (Lacoste \& Johnsen, 2015). In addition, there is a limited understanding of the impact of power asymmetry within sustainable supply chain relationships from the IMP interaction perspective (Johnsen et al., 2016).

Power asymmetry in the sustainable supply chain

In business relationships, the implementation of sustainability in supply networks concerns the application of power in supplier-buyer relationships, a retailer can coercively enforce its suppliers to act in response to its requirements (Maglaras et al., 2015). Furthermore, Simpson and Power (2005) found that a relational approach is more powerful than coercion when considering environmental performance while other studies emphasise trust and cooperation are essential relational elements for the implementation of sustainability (Geffen \& Rothenberg, 2000). Moreover, environmental and social sustainability goals become the major concerns for most companies; the literature highlights the fact that it is vital to make a fair balance between both types of goals in combination with the economic sustainability, which is fundamental for companies dealing with costs and revenues (Stone \& Wakefield, 2000).Shi et al., (2017) evaluated the economic and environmental performance in relation to the concept of power in the fashion supply chain and found that the party with less power has 
more drive to make a sustainable effort to achieve a greater profit. In most cases, this involves a greater sustainable investment by the fashion supplier than the retailer.

Organisations respond to social sustainability issues by shaping their business strategies (Pagell et al., 2010) because social sustainability issues pressure organisations and their practices (Paulraj, 2011) through external stakeholders' expectations (Porter \& Kramer, 2006). If these issues are addressed at the supply chain level, organisations can achieve sustainability performance goals (Paulraj, 2011). Supply chain operations and management are vital to create value and develop competitive strengths for organisations (Burgess et al., 2006) and environmental and social performance of an organisation will be affected by its suppliers and the organisations' practices and operations will be affected by the external pressure more, which are resulted from ethical dilemmas (Tate et al., 2010). Therefore, collaboration has been considered and supported as the best way to manage supply chains to achieve sustainability goals (Vachon \& Klassen, 2008; Alvarez et al., 2010), otherwise, large organisations will handle with problems unilaterally and force their suppliers to adopt codes of conducts (Pedersen, 2009).

Having identified the reasons for application of power, it is relevant to understand in sustainable supply chain to what extend the power is applied to each economic, environmental and social dimensions of sustainability and how asymmetric relationships are coordinated and achieve sustainability. Hence, Pullman et al., (2009) suggested that the impact of power influence on performance needs to be investigated in the sustainable supply chains. Moreover, understanding the effect of power on environmental and social sustainabilityhas overlooked in sustainable supply chain research (Chen et al., 2017; Koksal et al., 2017).

Buyer power is one of a number of variables considered by Dou et al., (2018). In their 
research, the findings suggest that the biggest influence that enables suppliers to adopt environmental practices is top management support in the buyer company. Other than geographical proximity, relationship factors are the next most influential. These include asymmetrical power of buyer over first-tier supplier and first-tier supplier over the second tier; as well as the perceived risk, shared by suppliers, that the buyer could disintermediate the supply chain and deal directly with the second-tier supplier. Hence trust is also important. The authors go on to assert that the buyer is unconcerned by this particular threat, and that the second-tier suppliers consider adopting environmental improvements as a way to address the power imbalance and give them more bargaining power to enter new supply chains (Dou et al., 2018).

\section{Power asymmetry in the market place}

Small suppliers play an important role in the fashion industry but also retailers' dominance is an important characteristic to consider in supply chain relationships (Johnsen and Ford, 2008). Suppliers' interactions with retail buyers influence the dominance and change the power structures in relationships (Meehan \& Wright, 2012). Meehan \& Wright (2012) have reported that, there is a dramatic shift in the balance in power, from suppliers to retailers. This may have some consequences for small suppliers by affecting their competitive advantage (Hines and McGowan, 2005). This could also be disadvantageous in deals with large retailers (Hingley, 2005) and particularly in the context of a gradual move into more private label goods: produce exclusively for retailers, sold under the retailers' own brands. In such conditions, the retailers take control of branding over the supplier (Meehan and Wright, 2012).

The fashion industry epitomises the use of outsourcing, delocalized production systems and decentralised management systems associated with environmental and social sustainability 
issues (Camuffo, Romano \& Vinelli, 2001; Forza \&Vinelli2000). Therefore, a typical fashion supply chain requires a combination of activities that need to be coordinated across several countries and organisations (Abernathy et al., 1999) because outsourcing in developing countries involves the risk that local suppliers and sub-suppliers may engage in unethical practices such as child labour, exploiting workers' rights or lack of hygiene standardsin order to keep their production costs low (Taplin 2014; Oxborrow and Lund-Thomsen, 2017). On the other hand, maintaining sustainability in terms of environmental impact and corporate social responsibility become increasingly difficult for buyer organisations as the number of suitable suppliers are limited (Runfola \& Guercini 2012). Therefore, the negotiation power of buyers in price would be decreased as a result of a limited amount of suppliers. This may affect the costs of supply; therefore, the negotiation power of retailers is reduced (Gadde \& Håkansson, 2001).

\section{Collaborations in sustainable supply chains}

Supply chain collaboration has been the focus of various authors (Simpson and Power, 2005; Alvarez et al., 2010; Swami and Shah, 2013; Walker et al., 2012; Kim et al., 2010), and power relationships in supply chains have been identified as important as they determine the management of sustainable supply chains (Simpson et al., 2007; Pagell et al., 2010; Toubolic et al., 2014). Further to this, in order to accomplish the economic and environmental sustainability goals a coordination and commitment is required from the supply chain members (Swami and Shah, 2013).

Zhang et al., 2009) depicted that collaborative relationships are less likely to be maintained if the actions of a party are penalised or less efficient to contribute to the relationship. Furthermore, collaboration presents benefits for sustainable supply chains through a number of relational mechanisms, in other words, the relationship between supply chain collaboration 
and enhanced sustainable supply chain performance is mediated. A number of authors have shown that improved trust as a result of collaboration enhances sustainable supply chain performance (Alvarez et al., 2010). Collaboration offer firms to access resources that they do not have or which are limited (Zacharia et al., 2009).Collaborations are considered to reduce transactional costs, and improve service level, flexibility and performancein relationships (Gulati \& Sytch, 2007; Nyaga et al., 2010; Wagner et al., 2010).

Vachon and Klassen (2008) examined the role of supply chain collaboration in environmental management and manufacturing performance. They found that collaboration is beneficial for implementation of green practices with suppliers (Vachon, 2007). Simpson et al. (2007) found that suppliers were more responsive to their buyers' environmental performance requirements but this involves a higher level of relationship specific investments (Pagell and $\mathrm{Wu}, 2009)$. However, this may be obstructed by the application of power by buyers in the supply chains (Toubolic et al., 2014).

\section{Adaptation}

Agreeably, companies in business relationships are expected to adapt to each other's requirements to the extent that how dependent they are on partner's resources (Hallen et al., 1991). Adaptation in a relationship can be processed by both sides; suppliers regularly adapt their processes and products to meet specific needs of their most important buyers. On the other hand, manufacturers organised their products and production systems in response to changes in components suggested by their suppliers. These adaptations enable partners to improve performance in operations, reduce costs or create dependence (Anderson \& Weitz, 1992; Pulman et al., 2009). Adaptations are made in order to increase transactional effectiveness in supply chain relations and eventually improve operational performance. Furthermore, suppliers may make process; product or service adaptations to full fill powerful 
partner'sneeds.In return, suppliers expectthat the powerful partner will respond with more encouraging transaction terms (Nyaga et al., 2013). Adaptations also enable firms to develop efficiencies in their transactions, build unique capabilities and accumulate resources that are characteristic of the relationship (Dyer \& Singh, 1998). Moreover, partners might have differences in their perceptions and expectations in supply chain relationships and these differences may have important destructive effects on performance (Nyaga et al., 2010). Consequently, adaptive behaviour is expected that firms involved in supply chain relationships and improve operational performance and progress towards achieving sustainable goals in supply chains.

\section{Conceptual development and typology to examine how small suppliers deal with the retail buyer power in asymmetric relationships within the sustainable fashion supply chain}

A significant number of researches have conceptualised power in traditional buyer-supplier relationships (Ireland and Webb, 2007; Thomas et al., 2010; Meehan and Wright, 2012; Chicksand, 2015, Nyaga et al 2013; Lacoste \& Johnsen, 2015). These researches agree that power is a central construct in supply chain management, but power has been seen as destructive in buyer-supplier relationships (Cox, 2001 and Nyaga et al., 2013) On the other hand, some argued that power is not destructive (Belaya et al., 2009; Hingley,2005). However, in this research, the focus is moved on sustainable buyer-suppliers relations from traditional buyer-supplier relations. In this regard, the application of power and suppliers' responses may significantly be different in sustainable supply chains. (Pagel et al., 2010) depicted that buyers do not apply their power to their suppliers within sustainable supply chains and see them as strategic partners. Moreover, collaboration improves sustainable 
performance through knowledge sharing and communication (Cheng et al., 2008; Alvarez et al., 2010). Cooperation with suppliers has been considered as a critical factor of creating sustainable supply chains (Pagell \& Wu, 2009).

In the literature review, the application of power by retail buyers within supply chains, based on economic, environmental and social concerns, we aim to explore how small suppliers deal with retail buyers' power and contribute to sustainable goals. The concept of power asymmetry and sustainability and its triple-bottom line namely economic, environmental and social were combined to develop the typology outlined in Table 1. Koksal et al., (2017) argued that there is a need for triple bottom line approach, it is very rare to see in one research paper but we provide insides from each dimension of sustainability and combined with power perspective (Dou et al., 2018). The typology indicates how each (triple-bottom) individual sustainable goal is manifested in retail buyers and suppliers relationships and guides the development of the empirical study.

\section{Insert Table 1 here.}




\section{Research Design and Methods}

\section{Qualitative Data Collection and Sampling}

The research design adopts a multiple exploratory case study approach (Yin, 2003) to enable rich data to be gathered on the experience of in asymmetric fashion supply chain relationships. The research project took a qualitative approach to overcome some of the methodological challenges associated with studying small supplier firms. Primary data was collected through twelve interviews with six small fashion firms. Table 2 provides details of participants.Purposive sampling was employed for the choice of participants for interviews to fit the criteriaof being the owner-manager of asmall fashion supplier and able to provide insights into the phenomenon being under investigation, in order to maintain the consistency in data collection and gathering of the complete set of knowledge from experts. Analysis of two pilot interviews enabled us to explore further the small fashionsuppliers' strategies in dealing with the application of power. Participants all had five or more years of experience in production processes and supply chain relations with the fashion retailers. Therefore, they were able to provide depth answers to our interview questions. Participants' companies are all situated in Istanbul in Turkey. The Istanbul Textile Export Association (ITKIB)'s membership data base was used for selecting suitable fashion firms. Three selection criteria were used in the selection of participant firms: a) regular exporters, b) member of ITKIB, and c) small fashion supplier firms implementing sustainability policies.

Interview questions commencedwith the demographics of participants followed by the topical areas in discussions including; retailers power, areas of power application and how, dealing with the power application within sustainable supply chains. These themes were drawn from current literature on industrial marketing (Johnsen \& Ford, 2008, Lacoste and Johnsen, 2015, and Chicksand, 2015) and sustainable supply chain literature (Elkington, 2002; Seuring\& 
Muller 2008; \&Toubolic and Walker, 2015b) were deemed to be core to an exploration of the role of power application withinsustainable fashion supply chain relations.

\section{Insert Table 2 here.}

\section{Data Analysis}

NVivo 11 qualitative data analysis software was used to conduct data analysis. Interviews were tape- recorded and transcribed and the data collected in Turkey was translated into English. Interviews were in-depth and semi-structured, lasted between 55 minutes to 75 minutes. The transcripts were annotated to generate first level coding (Miles \& Huberman, 1994). A coding tree was generated, based on emerging themes arising from the interviews based on codes for the further steps in reducing, displaying and interpreting the analysed data and followed the recommendations of Miles \& Huberman (1994) and Bryman (2008) for thematic analysis. The analytical approach was chosen in this research to relate the interview data to research question using themes derived from data analysis. The analysis resulted in a number of common issues, including those raised by the fashion suppliers themselves in discussion, as well as those apparent in, or in contrast to the literature. This was iterative way to identify themes and categories.As the number of categories developed, cross-referencing was used to combine similar categories for all participants and was then reviewed with the aim to reduce the number of categories. These common patterns and categories were discussed in findings and discussion.

The Meta-matrices (Table 3) were used for the cross-case analysis (Miles \& Huberman, 1994). Meta-matrices, in this research, provided bothanalytical generalisations from the individual case study findings, whilegenerating a holistic picture of intra and inter-firm interpretations, thus providing both external and internal validity (Yin, 2003). This approach 
supported our intra case comparisons and highlighted similarities and distinctions between the case companies, enabling us to draw conclusions from the findings of this empirical study.

Insert Table 3 here. 


\section{Empirical Findings}

In this section, the research findings addressed the first objective ofthe research: 'To identify the application of power within the sustainable fashion supply chains' by identifying the application of power by retail buyers within the sustainable fashion supply chain. The findings from the case studies (see Table 3) are used to answer the research questions by revealing the application of power in asymmetric relationships within the sustainable fashion supply chains and illustrate how suppliers responsehas implications in this context.

Retailers apply their power by enforcing fashion suppliers for collaborationsand by extending their responsibilities in order to achieve their performance goals.

\section{1) Application of Power}

\section{Enforcing Collaborations and Adaptations}

Widespread international supplier connections empower large fashion retail buyers to compare different prices, quality and suppliers globally, which reflects on negotiations as retailers have the ability to make global comparison in their relationships with fashion suppliers but the geographical proximity of possible fashion suppliers globally does not serve well to the immediateordering needs of fashion retailers and their economic, environmental and social sustainability goals. However, Turkish fashion suppliers' geographical proximity has been an advantage for meeting the immediate supply needs of fashion retailers in Europe and serves their sustainability goals economically, environmentally and socially.

Economic, in operational areas, retail buyers enforce fashion suppliers to collaborate in reducing the cost in fashion designing by establishing internal design houses, manufacturing, packaging and delivery of finished items in order to increase their revenue. On the other hand, in strategic areas, retailers enforce fashion suppliers to adopt new manufacturing technologies to manufacture small scale orders and cope with the variations of the orders because variations in fashion manufacturing cost more to the suppliers, there is a higher risk 
of loses in manufacturing process of highly varied orders. Furthermore, fashion suppliers adopt their outsourcing activities according to retailers' requirements. Turkish fashion suppliers are enforced to collaborate and adoptin operational and strategic areas. This was the condition of retailers and suppliers were supported through collaborations in technological and managerial processes by the fashion retailers in order to achieve economic sustainability goals.

Environment, fashion suppliers are enforced to collaborate and adapt in operational areas in efficient energy systems and water use in manufacturing, eliminating harmful chemicals, implementing sustainable process code of conduct and reducing the impact of delivery fashion items in order to improve process efficiency were enforced by retail buyers. On the other hand, in strategic areas, fashion suppliers are enforced to improve their environmental standards and obtain certifications ISO14001 and developing transparent information sharing channels with the retailers.

Social, regular employee training, workplace ethics, and implementing the policy of fair labour pay and removing gaps are the main requirements of retailers in operational areas. On the other hand, in strategic areas, protecting retailers' reputation and brand are the responsibilities of fashion suppliers' involvement in charitable events and not sharing retailers' information and practices with third parties. Furthermore, regular inspections are also emphasised by the retail buyers as obligations of suppliers to maintain social sustainability goals within sustainable fashion supply chains.

\section{Extension of Responsibilities}

Fashion retail buyers prioritise ethic in material choices and sourcing, manufacturing processes and employee rights within sustainable fashion supply chains because of the ethical process and practices in these areas influence the brand image and reputation in the market place. These are the preconditions in relationships and fashion suppliers are required to 
comply with these without any objections in return. In deed fashion suppliers were offered contracts that extend their responsibilities in thoseareas. After enforcing the suppliers into collaborations and adaptations in operational and strategic areas, this is the third stage in the application of power within sustainable fashion supply chains; extending responsibilities, which is further than applying into practices, to enforce the fashion suppliers to be more committed to the retail buyers' sustainable policies and gain a chance to involve for further sustainability strategy developments within the fashion supply chain.

The extension of responsibilitiesin raw material purchase, production processes and employee rights also concern transparency in decisions and communicationswith fashion suppliers. Transparency in relationships improves the level of trust and commitment between players, so that unethical practices are exposed. Moreover, providing feedback and asking the needs of fashion suppliers are considered to be ethical practice in relationships and allow and encourage suppliers to be involved in decisions and processes as this indicates the retailer has no intention of exhibiting opportunistic behaviour and taking advantages of the fashion suppliers. It also emphasises the fashion retailers' focus on improving performance and service in order to enhance their competitive advantages (Nyaga et al., 2013). Therefore, Retailers, by extending their responsibilities for ethical practice to suppliers, are making suppliers responsible for the ethical practice, and risk of non-compliance, throughout the whole supply chain to the final point of consumption. In other words, retailers use their power to absolve themselves of risk and pass it on to the supplier.

\section{2) Dealing with the Application of Power: Suppliers' responses}

The second objective of the research: 'To understand how suppliers deal with the buyer power within the sustainable fashion supply chains' was answered by exploring the responses of fashion suppliers in more detail (Table 3). 
Fashion suppliers deal with the application of power by adopting and collaborating with retail buyers in fashion outsourcing, employment, production, delivery and managerial practices to improve performance of the retail buying company in economic, environmental and social aspects of sustainability.

\section{Economic sustainability}

Production performance: developing the capabilities of fashion suppliers has been considered an important contribution to production performance because fashion retail buyers offer branded products to their customers in highly competitive markets. Therefore, capability development has been encouraged and supported by the retail buyers in collaborations, otherwise; retailers would not keep their integrity in highly competitive markets. Turkish fashion suppliers offered not only cost effective, fast and flexible fashion production, design and packaging processes to the retail buyers, but also they offered improvements in processes before, during and after the production of fashion items by adapting new manufacturing technology and collaborating with retail buyers.

Uncertainty through these stages was minimized, small fashion firms emphasised dealing with the uncertainty in fast production process decisions because suppliers need to communicate as fast as possible before taking any action in production processes which directly influence the economic performance of retailers. Therefore, small fashion suppliers developed their own internal design house and employee capabilities in order to meet retailer's economic sustainability requirements at the shortest time possible. Internal design houses also serve as innovation hubs for small fashion firms to proactively offer new competitive designs and production techniques to their large fashion retailers. The findings concur with van Hoek (2000). These adaptations and collaborations are the responses of fashion suppliers which offer cost effectiveness and revenue increase to meet sustainable economic goals. 
Sales Performance: entry price which is the unit price paid for the ordered products to the suppliers, and exit price represents the percentage of discount at the end of the sales season. Turkish suppliers position themselves as fast, high quality producer but their prices are higher than Asian fashion suppliers' prices, however, the exit price shows that Turkish fashion items were discounted less in the retailers' stores than Asian fashion items. This is important for retailers' sales performance because they make higher profits from Turkish fashions. The gap between entry and exit price is less than Asian fashion items, this shows the retailers' sales performance is high. Therefore, this price strategy supported fashion retail buyers economic sustainability goals by minimising their revenueloss. The finding provides an alternative approach to Johnsen and Ford (2006) who stated that supplier-buyer relationships develop so that large companies dominates the relationship with a focus on cost reduction rather than responsiveness.

\section{Environmental sustainability}

Protecting and performing: fashion suppliers have collaborated in environmental issues and adopted many policies in production processes to overcome the environmental concerns of retail buyers within fashion supply chains. The actions have been taken to overcome environmental issues within the fashion supply chains by fashion suppliers, including energy efficient systems for use in manufacturing, reduction of packaging, eliminating harmful chemical processes and waste reduction during manufacturing processes in order to improve environmental performance. On the other hand, environmental procedures such as employee training and awareness obtaining ISO 14001 certification, complying with the industry code of conduct have been adopted and implemented by fashion suppliers within the sustainable fashion supply chains. Furthermore, transparency has become very important in environmental responsibility commitments and performance improvements, therefore, 
fashion suppliers and retail buyers share transparent information regarding environmental processes to protect the environment.

\section{Social sustainability}

Brand Performance and Ethics: Fashion suppliers considered that supplying to high street retail brands would be beneficial for developing their own manufacturing presence in supply chain networks globally. They may gain reputation and strengthen their competitive advantage; it may help them to prevent competitors from entering the market in line with the Cox (2001). However, retail buyers inspected fashion suppliers' ethical activities. Fashion suppliers demonstrated their ethical stance in relationships and acknowledged the consequences of unethical business practises on their relationships and the retailers' brand value and performance. Ethical practises of fashion suppliers are vitally important and arepart of the retailers' brand equity thus; there was a very little tolerance to any mistakes made by fashion suppliers in the ethical processes. Therefore, Turkish fashion suppliers complied with the ethical code of conducts at every stage in transactions and relationships including inspections, transparency in communications and procedures from materials to production processes. Moreover, employees training in ethical issues in workplace, consequences, and gender pay gap awareness have been considered as vital in brand performance of the retailers. The cost of all these activities has been negotiated and agreed in buyer-supplier contracts. This was the cost of developing environmental sustainability for fashion suppliers. Therefore, fashion suppliers gained a position to involve through extended ethical responsibilities by providing feedbacks about outsourced materials and processes that support large fashionretailers' brand performance and reputation. This is consistent with Dou et al., (2018).

\section{3) Implications for Sustainable Fashion Supply Chain}

When a buyer organisation is forced by the market dynamics, it reflects this on to suppliers by requiring higher commitments from them. This indicates the emergence of one 
distinguishing characteristic of sustainable supply chain management. This also dictates the buyer organisation to take responsibility and involve supply chains as far as it could for an economic reason (Seuring, 2004; Kogg, 2003, and Preuss, 2005). This influences the collaboration with suppliers in environmental performance and social performance (Seuring and Muller, 2008).

Here, the implication for sustainable fashion supply chain is that the retailer buyers enforce suppliers to collaborate and adopt sustainable practices in order to extend the sustainable products' life cycle. In addition, the risk of reputation loss also plays an important role in this enforcement of power within the sustainable fashion supply chains. On the other hand, fashion suppliers are enforced into collaborations, adaptations and extension of responsibilities in order tobuild process efficiency in fashion supply chains are followed retail buyers request performance improvement from thefashion suppliers in economic, environmental and social aspects of sustainability.

Implementation of sustainability suggests that there are two important stages to take into account in sustainable fashion supply chains; the first is to develop sustainability goals in processes improvement and the second is to develop sustainability goals in performance improvement in order to achieve economic and social sustainability goals within fashion supply chains.

Initially buyers use their power to force transactional contracts on suppliers. However, suppliers use the opportunity to meet the ever more complex product range requests and efficient processes required, to enhance their bargaining power and develop more collaborative relationships with their retail buyers. In turn, suppliers aim to process orders quickly, rather than deal with the consequences of unpredictable seasonality, and hope that the extensive global markets of their retail buyers will enable them to gain market knowledge and help them win business with other retailers. As a result, Turkish manufacturers have 
invested in developing quick response processes, and capabilities to help secure competitive advantage and supplier power.

The findings indicate the fact that adopting technology and managerial processes are important to overcome unpredictable seasonality. Timing and speed of production are also important determinants to achieve economic sustainability through adaptation of manufacturing technology and planning by Turkish fashion suppliers in asymmetric relationships.

\section{Discussion}

In fashion supply chains, power asymmetry is evident and remains challenging for fashion suppliersas a result of the increasing power of retail buyers (Oxborrow \& Brindley, 2014 and Hingley et al., 2015). The findings are in line with the earlier study of Meehan and Wright (2012) with reference to the dramatic shift in the balance of power, from suppliers to retail buyers. The findings identified the application of power affect the implementation of economic, environmental and social sustainability policies that enforce fashion suppliers to collaborate and adapt in the directions that retail buyers prefer. The application of power is found in economic sustainability policies in relation to cost effectiveness, revenue increase and contractual decisions. Moreover, the application of power in environmental sustainability policies is also evident in energy and resource efficient manufacturing, packaging, delivery and elimination of harmful chemicals in processes, and waste management. Lastly, the application of power is found in social sustainability policies in relation to employee training, charitable events, ethics and retail buyers' reputation and brand image, and transparency in communication. The findings have addressed the gap in the sustainable supply literature, stated by (Walker et al, 2012), the concept of power and power relationsare still limited in sustainable supply chain research. Fashion suppliers are consistently more committed to the 
retail buyers in order to deal with process and performance improvements. This is consistent with Shi et al., (2017).

The discussion follows the themes drawn from the framework (Table 1), which guided this research to examine fashion suppliers in order to explore how they deal with the retail buyer power within the sustainable fashion supply chains. In particular, this research facilitates an inductive approach, linking industrial marketing management literature to sustainable supply chain management literature through the concept of asymmetric power, to which we turn for amore detailed conceptual explanation of how sustainable goals can be achieved in asymmetric relationships within the fashion supply chains. This is reflected in Table 1, which shows the inductive process from primary data collected from the case, cross-referenced to asymmetric power concepts, and linkingthese to sustainability approaches, whilst highlighting the importance ofconsidering sustainable supply chain management (Seuring and Muller 2008 and Toubolic \& Walker 2015a and 2014).The following section answers the third objective of the research indetail: 'To understand the implications for sustainable fashion supply chains'.

\section{Economic Sustainability}

The application of power creates collaboration opportunities for fashion suppliers in performance and process improvements within sustainable fashion supply chains (Lacoste \& Johnsen 2015). Furthermore, retail buyers did not apply their power as a penalty mechanism within sustainable fashion supply chains, this does not concur with (Lee \& Johnsen 2012 and Terbent \& Ashenbaum 2012) because through enforcements into collaborations and adaptations fashion suppliers improved the processes and also improved the performances that support retail buyers' sustainability goals. Moreover, retail buyers have been interested in cost reduction in outsourcing activities in supply chain exchanges. This has been found out by many supply chain researchers (Taplin 2014; Belaya et al., 2009 and Johnsen and Ford, 
2006) but our findings has suggested that processes efficiency in production provides a better sales performance. This is how economic sustainability goals are achieved in sustainable supply chains in addition to cost reduction. Furthermore, entry and exist price strategy of fashion suppliers improve the sales performance of the retail buyer and reduce the revenue loss which serves the economic sustainability goal.This is different from the findings of Johnsen \& Ford (2006) stated that large retail buyer focuses on cost reduction rather than responsiveness with trust and commitment not easily achieved.

Fashion retail buyers did not apply their power in price negotiations with Turkish fashion suppliers although they have this ability to do so because fashion suppliers' process and performance improvements and efficiencies improved the sales performance of the retail buyer, compare to their major competitors that are the manufactures in Asian countries. This indicates the fact that, the negotiation power of retail buyers in price would be decreased as a result of a limited amount of suppliers holds both process and performance efficiency in production to achieve economic sustainability (Gadde \&Håkansson, 2001).

\section{Environmental Sustainability}

Turkish fashion suppliers are forced into collaborations to achieve environmental sustainability goals within supply chains. Collaborations have improved sustainable performance through knowledge sharing and frequent communication; these collaborations have improved the level of awareness of environmental sustainability issues more among the fashion suppliers (Cheng et al., 2008; Alvarez et al., 2010). Environmental issues and responsibilities create more relational bonds between retail buyer and fashion suppliers to achieve green practices consistent with (Simpson \& Power, 2005 and Vachon \& Klassen, 2008)

Environmental sustainability policies are set to achieve resource efficiency and responsible use of sources. Therefore, Turkish fashion suppliers have required more adaptations and 
commitment to meet the environmental performance expectations of retail buyers (Chen et al., 2017 and Seuring \& Muller, 2008). This also reflects Simpson et al., (2007)'s view of being more responsive to the buyers' requirements in environmental sustainability. Collaborations become very important to implement new adopted practices and procedures. This concur with Pagell \& Wu's (2009) findings that collaboration has been considered as critical factor of creating sustainable supply chains. However, retail buyers applied their power to support adaptations process of suppliers. This addresses the work of (Touboulic et al., 2014) stated that limited understanding of power application in environmental sustainability in supply chains.

\section{Social Sustainability}

Fashion suppliers strengthened their position by extending their ethical responsibilities upstream in the supply chain, such as materials sourcing, to build the reputation attributed to both their retailers' brands and their own profile. This is consistent with Dou et al., (2018)'s work, stated that second-tier suppliers consider adopting environmental improvements as a way to address the power imbalance and give them more bargaining power to enter new supply chains.Moreover, fashion suppliers' ethical compliance is well recognised by fashion retailers in relation their brand performance because brand performance is very important for fashion retailers as the retailers take control of branding over the supplier (Meehan \& Wright, 2012).A limited number of fashion suppliers globally meet the ethical standards of fashion retailers. Turkish fashion suppliers focused on this issue and built on this that help them to prevent the competitors in fashion supply chains. This has provided collaboration opportunities with the retailers. Fashion suppliers demonstrated that adopting ethical procedures to support social sustainability performanceand extending responsibilities to eliminate the adverse effects of power application of retailers in asymmetric relationshipsand 
create interdependencies (Cox et al., 2004). This concur with (Gadde \&Hakansson 2005), p. 106. Power is applied in a more constructive way.

Fashion suppliers position themselves as they comply with the ethical code of conduct of their retailer customers which is a big commitment to the retailers' brand performance: Indeed, Cox (2001) states that the supplier can position itself in a powerful position successfully by preventing the competitors from market entry. However, Cox did not provide any finding how supplier can achieve this. The findings provided how fashion suppliers prevent the competitors as they adopt and extend the responsibilities which improve ethical performance of the retailers' brand and achieve social sustainability goals.

\section{Conclusion}

Long and established relationships of Turkish fashion suppliers with European retail buyers have a positive impact on supply chain integration and relationships. In addition, Turkish suppliers' capability developments in operational and strategic aspects through interactions with various buyers globally support them to achieve economic and social sustainability requirements of retail buyers in Europe. In addition, geographical proximity to Europe also play important role to achieve environmental sustainability within supply chains. Turkish suppliers demonstrated that interactions with powerful partners within sustainable supply chains provide more opportunity to find ways to deal with application of power.

The conceptual developments of the paper aimed to contribute to emerging theoretical discussions on the nature of asymmetric relationshipsand sustainability from an IMP interaction perspective. (Ford et al., 1986; Hakansson \& Snehota, 1995; Gadde \&Hakansson, 2001) and filled the gap in the IMP view that has been expressed by (Johnsen et al 2016). The research hascontributed to the field that explores the character of power asymmetry in sustainable supply chains (Johnsen \& Ford, 2008; Johnsen et al., 2016 and Toubolic et al., 
2014, Toubolic\& Walker 2015b). Building on an interaction approach, we set out to explore how fashion suppliers deal with power application by collaborating and adopting with retail buyers within sustainable supply chains. This study has built on previousresearch that has examined asymmetry in supplier buyer relationships (Johnsen \& Ford, 2008; Lee \& Johnsen, 2012) and sustainable supply chain management (Seuring and Muller, 2008).

Our researchis among the first to examine power asymmetry and sustainability within fashion supply chains by providing holistic approach in sustainability (triple-bottom line) rather than focusing on only one individual dimension. This is a significant theoretical contribution of the study, which has provided a typology by combining economic, environmental and social dimensions of sustainability, which is expressed by Koksal et al., (2017) and power asymmetry in fashion supply chains. The typology has provideda direction for analysing data by focusing on fashion suppliers strategies, while explaining how they overcome power asymmetries within sustainable supply chains. The utilisation of the typology, has added a further understanding to the work of the Industrial Marketing Purchasing (IMP) School and the interaction approach.

Our empirical contribution has been directed towards the exploration of the perspective of fashion suppliers in the asymmetric relationships in Turkey. The issues have previously been compounded by the need to overcome difficulties in reaching and convincing fashion suppliers to participate in academic studies. The approach adopted has provided direction for addressing this constant challenge for researchers in the sustainable supply chain field.

The main findings of the research derived from our first objective, identified power applications, mainly in the operational and strategic areas to achieve economic, environmental and social goals within sustainable supply chains as forms of enforcement of collaborations and extension of responsibilities. The second objective of this research 
provided clear understanding of how fashion suppliers deal with the application of power in the three dimensions of sustainability to create inter-dependencies in a number of ways was used by the fashion suppliers as response to power application. The third objective demonstrates the evaluation of power application and its implications for fashion supply chains: longer involvement of retail buyers in order to prevent risks and control on the other hand, collaborative opportunities with fashion suppliers and strengthening position within the competitive fashion suppliers.

All in all, dealing with the application of power has suggested different implications within sustainable supply chains than traditional supply chains, which have mainly focused on price competition, coercive power application and it has been considered as difficult to be stabilised.

\section{Future Research directions}

It is acknowledged that dealing with the power applications may be anenduring challenge for suppliers and as such a supplier must understand and evaluate its relationships with the buyer. This research has provided a platform for further longitudinal study with the research participants from both supplier and buyer sides. Future research should focus on the research design should explore sustainable approaches and power asymmetry in different sectors offashioncontext such as fast fashion, premium fashion, by examining both suppliers' and buyers' perspectives concurrently to offer rich observation and exploration. Moreover, different country contexts and their comparisons would provide richer insights and understanding in supply chain management. Furthermore, fashion suppliers can move from 'process support service' Ulaga \& Reinartz (2011) to provide 'performance process services' Lacoste and Johnsen (2015). This could be the future direction to look at power asymmetry may be overcome by providing different level of services within sustainable supply chains. 


\section{References}

- Abernathy, F.H., Dunlop, J.T., Hammond, J.H., \& Weil, D. (1999).A Stitch in Time: Lean Retailing and the Transformation of Manufacturing-Lessons from the Apparel and Textile Industries. New York: Oxford University Press.

- Anderson, E., \& Weitz, B. A. (1992). The use of pledges to build and sustain commitment in dis- tribution channels. Journal of Marketing Research, 29 (1), 18-34.

- Alvarez, G., Pilbeam, C., Wilding, R. (2010). Nestlé Nespresso a sustainable quality program: an investigation into the governance dynamics in a multi-stakeholder supply chain network. Supply Chain Management. International Journal, 15 (2), 165-182.

- Belaya, V., Gagalyuk, T., \&Hanf, J. (2009). Measuring Asymmetrical Power Distribution in Supply Chain Networks: What is the Appropriate Method? Journal of Relationship Marketing. 8, 165-193.

- Bensaou, M.(1999). Portfolios of buyer-seller relationships. Sloan Management. Review. 40 (4), 35-44.

- Benton, W., \& Maloni, M. (2005).The influence of power driven buyer/seller relationships on supply chain satisfaction, Journal of Operation Management. 23(1),1-22.

- Bryman, A. (2008). Research Methods and Organization Studies, Routledge, London.

- Burgess, K., Singh, P. J., \& Koroglu, R. (2006). Supply chain management: A structured literature review and implications for future research. International Journal of Operations \& Production Management, 26(7), 703-729.

- Casciaro, T., \& Piskorski, M. J. (2005). Power imbalance, mutual dependence and constraint absorption: A closer look at resource dependence theory. Administrative Science Quarterly, 50(2), 167-199.

- Camuffo A., Romano P., \& Vinelli A.(2001). Back to the Future: Benetton Transforms Its Global Network, Sloan Management Review. 43(1), 46-54. 
- Cheng, J.-H., Yeh, C.-H., \& Tu, C.-W. (2008). Trust and knowledge sharing in green supply chains. Supply Chain Management: An International Journal, 13(4), 283-295.

- Chen, X., Wang, X., \& Chan, H. K. (2017). Manufacturer and retailer coordination for environmental and economic competitiveness: A power perspective. Transport Research Part E. 97, 268-281.

- Chicksand, D. (2015). Partnerships: The role that power plays in shaping collaborative buyer-supplier exchanges, Industrial Marketing Management. 48(1), 121-139.

- Crook, T. R., \& Combs, J. G. (2007). Sources and con- sequences of bargaining power in supply chains. Journal of Operations Management, 25 (2), 546- 555.

- Cox, A. (2001). Managing with power: strategies for improving value appropriation from supply relationships. Journal of Supply Chain Management. Spring, 42-47.

- Cox, A. (2004). The art of the possible: Relationship management in power regimes and supply chains. Supply Chain Management: An International Journal, 9(5), 346356.

- Cox, A., Chicksand, D., \& Palmer,M. (2007). Stairways to heaven or treadmills to oblivion? Creating sustainable strategies in red meat supply chains. British Food Journal, 109(9), 689-720.

- Davies, A., Brady, T., \&Hobday, M., (2006). Charting a path toward integrated solutions. Sloan Management Review. 47, 39-48.

- Dou, Y., Zhu, Q., and Sarki, J. (2018) Green multi-tier supply chain management: An enabler investigation, Journal of Purchasing and Supply Management. 24 (2), 95-107

- Dubois, A., Gadde, L.(2000). Supply strategy and network effects-purchasing behaviour in the construction industry. European Journal of Purchase and Supply Management. 6, 207-215. 
- Dyer, J. H., \& Singh, H. (1998). The relational view: Cooperative strategy and sources of inter-organizational competitive advantage. Academy of Management Review, 23 (4), 660-679.

- Dwyer, F.R.(1980). Channel-member satisfaction: laboratory insights. Journal of Retail. 56, 45-65.

- Emerson, R.M. (1962). Power-dependence relations. In M.E. Olsen (Ed.), Power in societies. New York: Macmillan Publishing.

- Elkington J. (2002). Cannibals with forks: the triple bottom line of 21 st century business [reprint]. Oxford: Capstone.

- Emerson, R. M. (1962). Power-Dependence Relations, American Sociological Review. 27(2), 31-41.

- Eisenhardt, K. M. (1989). Agency theory: An assessment and review. Academy of Management Review, 14(1), 57-74.

- Ford, I. D. (1980). The development of buyer-seller relationships in industrial markets.European Journal of Marketing, 14(3), 72-84.

- Ford, I.D., Hakansson, H., \&Johanson, J. (1986). How do Companies Interact? Industrial Marketing and Purchasing, 1(1), 26-41.

- Ford, D. (2001). The development of buyer-seller relationships in industrial markets. European Journal of Marketing. 14, 5-6.

- Ford, D.,Gadde, L. E., Hakansson, H., \&Snehota, I. (2003). Managing Business Relationships, John Wiley, Chichester.

- Ford, D., Mouzas, S. (2013). Service and value in the interactive business landscape. Industrial Marketing Management. 42 (1), 9-17.

- Forza, C., \&Vinelli, A., (2000). Time compression in production and distribution within the textile-apparel chain, Integrated Manufacturing Systems. 11 (2), 138-146. 
- Gadde, L.-E. \& H. Håkansson. (2001). Supply Networks Strategy. Chichester, John Wiley \& Sons, 161-186.

- Gadde, L.E., Håkansson, H., (2005). Supply Network Strategies. John Wiley \& Sons, Chichester, UK.

- Gaski, J. F. (1984). The Theory of Power and Conflict in Channels of Distribution, Journal of Marketing. 48(2), 9-29.

- Geffen, C.A. and Rothenberg, S. (2000) Suppliers and environmental innovation: the automotive paint process. International Journal of Operations and Production Management. 20(2), 166-186.

- Gulati, R., \& Sytch, M. (2007). Dependence asymmetry and joint dependence in interorganizational relationships: Effects of embeddedness on a manufacturer's performance in procurement relationships. Administrative Science Quarterly, 52 (3), $32-69$.

- Hakansson, H. (1987). Product development in networks. In H. Hakansson (Ed.), Technological development: A network approach (pp. 84 -128). New York: Croom Helm

- Hakansson, H., \&Snehota, I. (1995). Developing relationships in business networks. London:Thomson.

- Hausman, A.,\& Johnston, W.J.(2010). The impact of coercive and non-coercive forms of influence on trust, commitment and compliance in supply chains. Industrial Marketing Management. 39 (3), 519-526.

- Hallen, L., Johanson, J., \&Seyed-Mohamed, N. (1991). Interfirm adaptation in business relation- ships. Journal of Marketing, 55 (4), 29-37. 
- Hines, T.,\&McGowan, P. (2005). Supply Chain Strategies in The UK Fashion Industry-The Rhetoric of Partnership and Realities of Power, International Entrepreneurship and Management Journal. 1(4), 519-537.

- Hingley, M. K. (2005). Power to all our friends? Living with imbalance in supplier retailerRelationships,Industrial Marketing Management. 34(8), 848-858.

- Hingley, M., Angell, R., \&Lindgreen, A. (2015).The current situation and future conceptualization of power in industrial markets. Industrial Marketing Management, 48(1), 226-230.

- Ireland, R. D., \& Webb, J. W. (2007). Strategic entrepreneurship: Creating competitiveadvantage through streams of innovation. Business Horizons, 50, 49-59.

- Johnsen, R. E., \& Ford, D. (2006). Interaction capability development of smaller suppliersin relationships with larger customers. Industrial Marketing Management, $35(8), 1002-1015$.

- Johnsen, R.E., \& Ford, D. (2008). Exploring the concept of asymmetry: a typology for analysing customer-supplier relationships, Industrial Marketing Management. 37(4), $471-483$.

- Johnsen, T. E., Miemczyk, J., \& Howard, M. (2016). A systematic literature review of sustainable purchasing and supply research: Theoretical perspectives and opportunities for IMP-based research. Industrial Marketing Management. 61, 130143.

- Kim, K.K., Park, S.H., Ryoo, S.Y., \& Park, S.K.(2010). Inter-organizational cooperation in buyer-supplier relationships: both perspectives. Journal of Business. Research. 63 (8), 863-869. 
- Koksal, D., Strahle, J., Muller, M., \& Freise, M. (2017). Social Sustainable Supply Chain Management in the Textile and Apparel Industry A Literature Review. Sustainability. 9, 100

- Kumar, N. (2005). The power of power in supplier-retailer relationships. Industrial Marketing Management, 34(8), 863-866.

- Lacoste, S., \& Johnsen, R. (2015). Supplier-customer relationships: A case study of powerdynamics. Journal of Purchasing and Supply Management, 21(4), 229-240.

- Lee, C.J., \& Johnsen, R.E., (2012). Asymmetric customer-supplier relationship development in Taiwanese electronics firms. Ind. Mark. Manage. 41 (4), 692-705.

- Lee, S.-Y., \& Klassen, R. D. (2008). Drivers and enablers that foster environmental management capabilities in small- and medium-sized suppliers in supply chains. Production and Operations Management, 17(6), 573-586.

- MacCarthy, B. L., \& Jayarathe, P.G.S.A. (2010). Sustainable collaborative supply networks in the international clothing industry: a comparative analysis of two retailers. Production Planning \& Control. 23(4), 252-268.

- Maglaras, G., Bourlakis, M., \& Fotopoulos, C. (2015). Power-imbalanced relationships in the dyadic food chain: An empirical investigation of retailers' commercial practices with suppliers, Industrial Marketing Management. 48, 187-201.

- Maloni, M., \& Benton,W. C. (2000). Power influences in the supply chain. Journal of Business Logistics, 21(1), 49-73.

- Meehan, J., \& Wright, Gillian, H. (2012). The origins of power in buyer-seller relationships, Industrial Marketing Management. 41(1), 669-679.

- Miles, M. B., \&Huberman, A. M. (1994). Qualitative data analysis: An expanded sourcebook.London: Sage. 
- Millington, A. (2008). Responsibility in the supply chain. In A. Crane, A. McWilliams, D. Matten, J. Moon, \& D. S. Siegel (Eds.), The Oxford handbook of corporate social responsibility. Oxford. p. 363.

- Mintzberg, H., \& Quinn, J.B. (1992). The Strategy Process: Concepts and Contexts. Englewood Cliffs, Prentice Hall.

- Munksgaard, K. B., Johnsen, R. E., \& Patterson, C. M. (2015). Knowing me, knowing you: Self- and collective interests in goal development in asymmetric relationships.Industrial Marketing Management, 48(1), 160-173.

- Nyaga, G. N., Whipple, J. M., \& Lynch, D. F. (2010). Examining supply chain relationships: Do buyer and supplier perspectives on collaborative relationships differ? Journal of Operations Management, 28 (2), 101-114.

- Nyaga, Gilbert N., Lynch, Daniel, F., \& Marshal, D., Ambrose, E. (2013).Power Asymmetry, Adaptation and Collaboration in Dyadic Relationships Involving A Powerful Partner, Journal of Supply Chain Management. 49 (3), 42-65.

- Oxborrow, L., \& Brindley, C. (2014). Disintermediation in the apparel supply chain, Journal of Fashion Marketing and Management. 18(30), 252-268.

- Oxborrow, L., \& Lund-Thomsen, P.(2017). Sustainable Supply Chain Management in Molthan-Hill, P. (ed), 2017. The business student's guide to sustainable management: principles and practice. (Principles for responsible management education series) $2^{\text {nd }}$ edition. Abingdon: Routledge. ISBN 9781783533190

- Pagell, M., \& Wu, Z. (2009). Building a more complete theory of sustainable supply chain management using case studies of 10 exemplars. Journal of Supply Chain Management. 45 (2), 37-56. 
- Pagell, M., Wu, Z., \& Wasserman, M.E.(2010). Thinking differently about purchasing portfolios: an assessment of sustainable sourcing. Journal of Supply Chain Manage.46 (1), 57-73.

- Paulraj, A. (2011). Understanding the relationships between internal resources and capabilities, sustainable supply management and organizational sustainability. Journal of Supply Chain Management, 47(1), 19-37.

- Pedersen, E.R.,\& Andersen, M. (2006). Safeguarding corporate social responsibility in global supply chains: how codes of conduct are managed in buyersupplier relationships. Journal of Public Affairs 6 (3-4), 228-240.

- Pedersen, E. R. (2009). The many and the few: Rounding up the SMEs that manage CSR in the supply chain. Supply Chain Management: An International Journal, 14(2), $109-116$.

- Pulles, Niels J., Veldman, J., Schiele, H., \&Sierksma, H. (2014).Pressure or Pamper? The Effects of Power and Trust Dimensions on Supplier Resource Allocation, Journal of Supply Chain Management. 50(3), 16-36.

- Pullman, M.E., Maloni, M.J., \& Carter, C.R.(2009). Food for thought: social versus environmental sustainability practices and performance outcomes. Journal of SupplyChain Manage. 45 (4), 38-54.

- Porter, M. E., \& Kramer, M. R. (2006). Strategy and society: The link between competitive advantage and corporate social responsibility. Harvard Business Review, 84(12), 78-92.

- Foreign and Commonwealth Office. (2014). Research and Analysis. Turkey: latest killer facts about the economy, https://www.gov.uk/government/publications/turkeylatest-killer-facts-about-the-economy/turkey-latest-killer-facts-about-the-economy, Accessed September 29, 2015. 
- Ritchie, B., \& Brindley, C. (2000). Disintermediation, disintegration and risk in the SME global supply chain", Management Decision. 38(8), 575 - 583.

- Rindt, J., \&Mouzas, S. (2015). Exercising Power in Asymmetric Relationships: the use of private rules. 48(1), 202-213.

- Sako, M. (1998). Does trust improve business performance? in Lane, C. and Backman, R. (Ed.), Trust within and between organizations: Conceptual issues and empirical application, (pp. 88-117).Oxford: Oxford University Press.

- Shi, X., Qian, Y., \& Dong, C. (2017) Economic and environmental performance of fashion supply chain: The joint effect of power structure and sustainable investment. Sustainability,9, 961 .

- Stone, G. W., \& Wakefield, K. L.(2000). Eco-Orientation: An Extension of Market Orientation in an Environmental Context, Journal of Marketing Theory and Practice, $8(3), 21-32$.

- Seuring, S. \& Muller, M. (2008). From a literature review to a conceptual framework for sustainable supply chain management. Journal of Cleaner Production. 16,16991710.

- Svahn, S., Westerlund, M.(2009). Purchasing strategies in supply relationships. Journal of Business and Industrial Marketing. 24 (3/4), 173-181.

- Swami, S., Shah, J. (2013). Channel coordination in green supply chain management. Journal of Operations Research Society. 64 (3), 336-351.

- Simpson, D.F. \& Power, D.J. (2005). Use the supply relationship to develop lean and green suppliers. International Journal of Supply Chain Management, 10(1),60-68.

- Simpson, D., Power, D., \& Samson, D. (2007). Greening the automotive supply chain: A relationship perspective. International Journal of Operations \& Production Management, 27(1), 28-48. 
- Taplin, I.M. (2014). Who is to blame? A re examination of fast fashion after the 2013 factory disaster in Bangladesh, Critical perspectives on international business. 10 $(1 / 2), 72-83$.

- Tate, W. L., Ellram, L.M., \& Kirchoff, J. F. (2010). Corporate social responsibility reports: A thematic analysis related to supply chain management. Journal of Supply Chain Management, 46(1), 19-44.

- Terpent, R., \&Ashenbaum, B. (2012). The intersection of power: Trust and Supplier Network Size: Implications for Supplier Performance, Journal of Supply Chain Management. 48(3), 52-77.

- Tokatli, N., \&Kizilgün, O. (2009). From manufacturing garments for ready-to-wear todesigning collections for fast fashion: Evidence from Turkey. Environment andPlanning, 41(1), 146-162.

- Thomas, R., Sargent, L. D., \& Hardy, C. (2010).Managing organizational change: Negotiating meaning and power-resistance relations. Organization Science, 22(1), 2241.

- Toubolic, A., Chicksand, D., \& Walker, H. (2014). Managing Imbalanced Supply ChainRelationships for Sustainability: A Power Perspective. Journal of The Decision Science Institute. 45(4).

- Toubolic, A., \& Walker, H. (2015a).Theories in sustainable supply chain management: a structured literature review. International Journal of Physical Distribution \& Logistics, 45, 16-42.

- Toubolic, A., \& Walker, H. (2015b). Love me, love me not: A nuanced view on collaboration in sustainable supply chains. Journal of Purchasing \& Supply Management, 21, 178-191. 
- van Hoek, R. I. (2000). Role of third party logistic services in customization through post-ponement, International Journal of Service Industry Management. 11(4), 374 387.

- Ulaga, W., \&Reinartz, W.J., (2011). Hybrid offerings: how manufacturing firms combine goods and services successfully. Journal of Marketing. 75, 5-23.

- Vachon, S. (2007). Green supply chain practices and the selection of environmental technologies. International Journal of Production Research, 45(18-19), pp. 4357-4379.

- Vachon, S., \& Klassen, R. (2008). Environmental management and manufacturing performance: The role of collaboration in the supply chain. International Journal of Production Economics, 111, 299-315.

- Vargo, S.L., \&Lusch, R.F. (2004). Evolving to a new dominant logic for marketing. Journal of Marketing. 68, 1-17.

- Wagner, S.M., \& Eggert, A., Lindemann, E. (2010). Creating and appropriating value in collaborative relationships. Journal of Business. Research. 63 (8), 840-848.

- Walker, H., \& Preuss, L. (2008). Fostering sustainability through sourcing fromsmall businesses: Public sector perspectives. Journal of Cleaner Production,16(15), 16001609.

- Walker, H., Miemczyk, J., Johnsen, T., \& Spencer, R. (2012). Sustainable procurement:Past, present and future. Journal of Purchasing\&Supply Management,18(4), 201-206.

- Yin, R.K. (2003). Case study research: design and methods. Sage, London.

- Zhang, C., Henke, J. W., \& Griffith, D. A. (2009). Do buyer cooperative actions matter under relational stress? Evidence from Japanese and U.S. assemblers in the U.S. automotive industry. Journal of Operations Management, 27 (6), 479-494. 
- Zacharia, Z. G., Nix, N. W., \&Lusch, R. F. (2009). An analysis of supply chain collaborations and their effect on performance outcomes. Journal of Busi- ness Logistics, 30 (2), 101-123. 
Table 1: Typology of how small suppliers deal with the retail buyers' power in asymmetric relationships within the sustainable fashion supply chain

\begin{tabular}{|c|c|c|c|}
\hline $\begin{array}{l}\text { Sustainability } \\
\text { Goals of Retail } \\
\text { Buyer }\end{array}$ & $\begin{array}{l}\text { Application of power by retail } \\
\text { buyer }\end{array}$ & $\begin{array}{l}\text { Suppliers deal with retail buyers' } \\
\text { power }\end{array}$ & $\begin{array}{l}\text { Indicators of the implications for } \\
\text { sustainable fashion supply chain }\end{array}$ \\
\hline Economic & 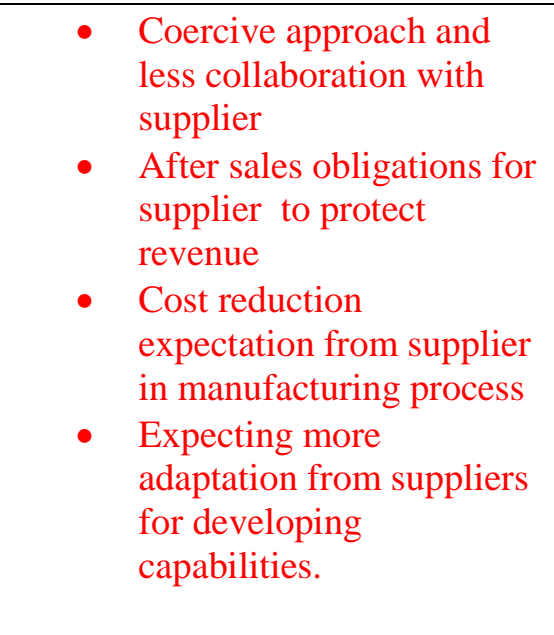 & $\begin{array}{l}\text { - } \text { Offered sales performance } \\
\text { increasing services by } \\
\text { suppliers } \\
\text { - Invest into cost saving } \\
\text { technologies } \\
\text { - Committing more into } \\
\text { collaborations } \\
\text { - Adaptation of retailers' } \\
\text { policies and standards } \\
\text { - Cost effectiveness without } \\
\text { compromising quality and } \\
\text { environmental performance }\end{array}$ & $\begin{array}{l}\text { Extension of sustainable product } \\
\text { life cycle } \\
\text { Retailers recognise suppliers } \\
\text { needs and provides support for } \\
\text { suppliers development needs for } \\
\text { creating sustainable competitive } \\
\text { advantage. } \\
\text { Retailer and supplier collaborate } \\
\text { in research and development for } \\
\text { new product design for cost } \\
\text { reduction } \\
\text { Fair profit and price issues are } \\
\text { discuss between retailer and } \\
\text { supplier }\end{array}$ \\
\hline Environmental & $\begin{array}{l}\text { - Coercive approach } \\
\text { - Enforcing suppliers to do } \\
\text { necessary investment into } \\
\text { and environmentally } \\
\text { friendly production } \\
\text { processes } \\
\text { Strict rules and guidelines } \\
\text { of retailers'authorization }\end{array}$ & $\begin{array}{l}\text { - Compulsory collaborations } \\
\text { with retailers in the process } \\
\text { of production and } \\
\text { responsible outsourcing } \\
\text { - Adaptation of sustainable } \\
\text { practices of retailers in } \\
\text { chemical and material use. } \\
\text { - Deal with the high costs of }\end{array}$ & $\begin{array}{l}\text { Retailers and suppliers } \\
\text { collaborate in environmental } \\
\text { issues such as reducing packing, } \\
\text { CO2 emission, energy and water } \\
\text { use to increase the } \\
\text { environmental performance and } \\
\text { reduce the risk of reputation loss } \\
\text { and damage. }\end{array}$ \\
\hline
\end{tabular}




\begin{tabular}{|c|c|c|c|}
\hline & $\begin{array}{l}\text { for environmentally } \\
\text { friendly processes in } \\
\text { production and } \\
\text { responsible outsourcing }\end{array}$ & $\begin{array}{l}\text { environmental protection } \\
\text { measures }\end{array}$ & $\begin{array}{l}\text { - Suppliers gain competency of } \\
\text { understanding environmental } \\
\text { issues regarding increasing } \\
\text { productivity in production and } \\
\text { use of resources }\end{array}$ \\
\hline Social & $\begin{array}{l}\text { - Enforcing the compliance } \\
\text { of ethical obligations in } \\
\text { order to protect employee } \\
\text { rights. } \\
\text { - Cost of ethical } \\
\text { requirements are added } \\
\text { on price negotiations with } \\
\text { suppliers }\end{array}$ & $\begin{array}{l}\text { - } \begin{array}{l}\text { Brand performance } \\
\text { improvement services by } \\
\text { suppliers }\end{array} \\
\text { - Suppliers comply with the } \\
\text { retailers ethical policies and } \\
\text { practices in employing } \\
\text { people and protecting their } \\
\text { rights } \\
\text { - Compulsory ethical } \\
\text { adjustments are maintained }\end{array}$ & $\begin{array}{l}\text { - Understanding ethical issues as } \\
\text { communication medium with } \\
\text { pressure groups } \\
\text { - Securing future relationships in } \\
\text { the supply chain. } \\
\text { - Retailer collaborates with } \\
\text { suppliers for their training in } \\
\text { sustainable practices and } \\
\text { protecting the reputation } \\
\text { - Suppliers understand retailers' } \\
\text { approach to ethical issues such } \\
\text { as labour practices and gender } \\
\text { pay }\end{array}$ \\
\hline
\end{tabular}


Table2: Company Profiles and Participants

\begin{tabular}{|c|c|c|c|c|c|}
\hline Suppliers & Participants & Employees & Production & Turnovers & $\begin{array}{l}\text { Retailer } \\
\text { Customer } \\
\text { Types }\end{array}$ \\
\hline $\begin{array}{l}\text { Supplier A } \\
\text { Manufacturer } \\
\text { exporter }\end{array}$ & $\begin{array}{l}\text { 1.General Manager } \\
\text { 2.Production } \\
\text { Manager }\end{array}$ & 1000 & $\begin{array}{l}\text { Circular Knitting } \\
\text { garment for women/men } \\
\text { (sportswear) }\end{array}$ & $\begin{array}{l}\text { 40-50 million } \\
\text { dollars yearly }\end{array}$ & $\begin{array}{l}\text { Specialist } \\
\text { store and } \\
\text { department } \\
\text { store }\end{array}$ \\
\hline $\begin{array}{l}\text { Supplier B } \\
\text { Manufacturer } \\
\text { exporter }\end{array}$ & $\begin{array}{l}\text { 1.Production } \\
\text { Manager 2.Owner }\end{array}$ & 380 & $\begin{array}{l}\text { Knitwear for women } \\
\text { and kids (Jumper, socks, } \\
\text { cardigan) }\end{array}$ & $\begin{array}{l}\text { 25-30 million } \\
\text { dollars yearly }\end{array}$ & $\begin{array}{l}\text { Specialist } \\
\text { store } \\
\text { department } \\
\text { store }\end{array}$ \\
\hline $\begin{array}{l}\text { Supplier C } \\
\text { Manufacturer } \\
\text { Outsourcer } \\
\text { Exporter }\end{array}$ & $\begin{array}{l}\text { 1.Export } \\
\text { Manager2.Owner }\end{array}$ & 150 & $\begin{array}{l}\text { Knitwear for } \\
\text { women/men } \\
\text { (T-shirts, polo shirts, } \\
\text { sweatshirts, tops, jersey } \\
\text { jackets, jersey pants, } \\
\text { dresses, skirts) }\end{array}$ & $\begin{array}{l}\text { 10-15 million } \\
\text { dollars yearly }\end{array}$ & $\begin{array}{l}\text { Specialist } \\
\text { store and } \\
\text { department } \\
\text { store }\end{array}$ \\
\hline $\begin{array}{l}\text { Supplier D } \\
\text { Manufacturer } \\
\text { Exporter }\end{array}$ & $\begin{array}{l}\text { 1.General Manager } \\
\text { 2.Part-Owner }\end{array}$ & 290 & $\begin{array}{l}\text { Circular Knitting, } \\
\text { Printing, embroidery, } \\
\text { Fabric Knitting and } \\
\text { Cutting for mid age } \\
\text { women and men } \\
\text { (Fancy and luxury } \\
\text { dress) }\end{array}$ & $\begin{array}{l}\text { 15-20 million } \\
\text { dollars yearly }\end{array}$ & $\begin{array}{l}\text { Specialist } \\
\text { store }\end{array}$ \\
\hline Supplier E & $\begin{array}{l}\text { 1.General } \\
\text { Manager2.Owner }\end{array}$ & 320 & Coat and Jacket Women & $\begin{array}{l}\text { 15-20 million } \\
\text { dollar yearly }\end{array}$ & $\begin{array}{l}\text { Department } \\
\text { store }\end{array}$ \\
\hline
\end{tabular}




\begin{tabular}{|c|c|c|c|c|c|}
\hline $\begin{array}{l}\text { Manufacturer } \\
\text { Exporter }\end{array}$ & & & & & \\
\hline $\begin{array}{l}\text { Supplier F } \\
\text { Manufacturer } \\
\text { Exporter }\end{array}$ & $\begin{array}{l}\text { 1.ExportProduction } \\
\text { Manager } \\
\text { 2.Owner }\end{array}$ & 155 & Knitting for Men (shirt) & $\begin{array}{l}\text { 5-6 million } \\
\text { dollar yearly }\end{array}$ & $\begin{array}{l}\text { Department } \\
\text { store }\end{array}$ \\
\hline
\end{tabular}


Table 3: Findings: Suppliers' Responses to the retail buyer power in asymmetric relationships within the sustainable fashion supply chain

\begin{tabular}{|c|c|c|c|}
\hline Suppliers & $\begin{array}{l}\text { Economic } \\
\text { Sustainability }\end{array}$ & $\begin{array}{l}\text { Environmental } \\
\text { Sustainability }\end{array}$ & $\begin{array}{l}\text { Social } \\
\text { Sustainability }\end{array}$ \\
\hline
\end{tabular}




\begin{tabular}{|c|c|c|c|}
\hline & $\begin{array}{l}\text { Reducing the cost of design process for } \\
\text { frequent changes in orders. }\end{array}$ & $\begin{array}{l}\text { Evaluating resource efficiency plans and } \\
\text { environmental impact. }\end{array}$ & \\
\hline $\begin{array}{l}\text { Supplier C } \\
\text { Manufacturer } \\
\text { Outsourcer } \\
\text { Exporter }\end{array}$ & $\begin{array}{l}\text { Adapting/Collaborating } \\
\text { Designing manufacturing process for small } \\
\text { orders } \\
\text { Increasing sales performance with cost } \\
\text { effective but quality offerings. } \\
\text { Working with third party suppliers which } \\
\text { are suggested by retailers }\end{array}$ & $\begin{array}{l}\text { Adapting/Collaborating } \\
\text { Transparent information sharing with } \\
\text { retailer and discussing contingency plans. } \\
\text { Continuous employee training for } \\
\text { environmental awareness. } \\
\text { Compliance with retailers' environmental } \\
\text { process standards }\end{array}$ & $\begin{array}{l}\text { Adapting/Collaborating } \\
\text { Staff training for workplaceethic Fair labour } \\
\text { practices. } \\
\text { Training staff for environmental awareness. } \\
\text { Transparent communication with retailer and } \\
\text { reporting }\end{array}$ \\
\hline
\end{tabular}




\begin{tabular}{|c|c|c|c|}
\hline $\begin{array}{l}\text { Supplier F } \\
\text { Manufacturer } \\
\text { Exporter }\end{array}$ & $\begin{array}{l}\text { Adapting/Collaborating } \\
\text { Providing tailor made solutions for product } \\
\text { design performance. } \\
\text { In house design workshop and cost } \\
\text { effectiveness. } \\
\text { Designing cost effective delivery processes. }\end{array}$ & $\begin{array}{l}\text { Adapting/Collaborating } \\
\text { Waste reduction for dying house process of } \\
\text { fabrics. } \\
\text { Employee training and encouraging } \\
\text { employees to develop their capabilities for } \\
\text { environmental awareness. } \\
\text { Material management to reduce the impact } \\
\text { on the environment }\end{array}$ & $\begin{array}{l}\text { Adapting/Collaborating } \\
\text { Fair payment and removing gender pay gap. } \\
\text { Promoting employees to keep them longer in the } \\
\text { company. } \\
\text { Transparent communication with retailers and } \\
\text { understand how to avoid the risk of damage on } \\
\text { retailers' fashion brand reputation. }\end{array}$ \\
\hline
\end{tabular}


